\title{
OPTIMASI FORMULA GRANUL EFFERVESCENT KOMBINASI EKSTRAK KELOPAK BUNGA Hibiscus sabdariffa L. DAN EKSTRAK DAUN Guazuma ulmifolia Lam.
}

\section{OPTIMIZATION OF EFFERVESCENT GRANULE FORMULA FROM Hibiscus sabdariffa $L$. CALYX EXTRACT AND Guazuma ulmifolia Lam. LEAF EXTRACT}

\author{
Dwi Nurahmanto, Marsalita Irine Prabandari, Bawon Triatmoko, Nuri \\ Fakultas Farmasi Universitas Jember \\ Jl. Kalimantan 37, Jember 68121 \\ Email: dwinurahmanto.farmasi@unej.ac.id (Dwi Nurahmanto)
}

\begin{abstract}
ABSTRAK
Guazuma ulmifolia Lam. dan Hibiscus sabdariffa L. dapat digunakan untuk menurunkan kadar kolesterol dalam darah. Penelitian ini dirancang untuk membuat sediaan granul effervescent dari kombinasi ekstrak daun Guazuma ulmifolia Lam. dan ekstrak kelopak bunga Hibiscus sabdariffa L. Jamu yang mengandung ekstrak tersebut biasanya memiliki rasa yang pahit. Formulasi dalam bentuk effervescent, dengan asam sitrat dan natrium bikarbonat sebagai sumber asam dan basa, dapat memperbaiki sifat yang kurang menyenangkan tersebut. Penelitian ini bertujuan untuk mengetahui formula optimum yang memiliki sifat fisik granul effervescent yang baik. Penelitian ini dilakukan berdasarkan metode desain faktorial dengan dua faktor dan dua level yang menghasilkan empat formula yaitu formula $1, a, b$, dan ab. Sifat fisik granul effervescent yang diuji adalah kelembaban dan waktu larut. Hasil menunjukkan bahwa peningkatan konsentrasi natrium bikarbonat dapat menurunkan kelembaban dan waktu larut. Sedangkan peningkatan konsentrasi asam sitrat justru sebaliknya. Formula optimum yang diperoleh dalam penelitian ini mengandung asam sitrat $600 \mathrm{mg}$ dan natrium bikarbonat $1440 \mathrm{mg}$. Formula tersebut memiliki komposisi yang sama seperti formula $b$.
\end{abstract}

Kata kunci: granul effervescent, Guazuma ulmifolia Lam., Hibiscus sabdariffa L.

\begin{abstract}
Guazuma ulmifolia Lam. and Hibiscus sabdariffa L. can be used to reduce blood cholesterol level. This study was prepared the effervescent granules from combination of Guazuma ulmifolia Lam. leaf extract and Hibiscus sabdariffa L. calyx extract. Jamu containing these herbs usually tastes bitter. Effervescent formulation, with citric acid and sodium bicarbonate as acid and base sources, may improve this unpleasant property. The aim of this study is to know the optimum formula which has good physical properties of effervescent granules. This study was done using factorial design method with two factors and two levels, which produced four formulas including formula 1, $a, b$, and $a b$.
\end{abstract}


The physical properties of the granules tested were moisture content and dissolving time. The results showed that the enhancement of sodium bicarbonate concentration could decrease moisture content and dissolving time. Meanwhile, the enhancement of citric acid concentration the opposite result. The optimum formula obtained from this study contained $600 \mathrm{mg}$ citrate and $1440 \mathrm{mg}$ sodium bicarbonate. This optimum formula had the same composition with formula $b$.

Key words: effervescent granules, Guazuma ulmifolia, Hibiscus sabdariffa. 


\section{Pendahuluan}

Daun jati belanda (Guazuma ulmifolia Lam.) dan kelopak bunga rosella (Hibiscus sabdariffa L.) secara tradisional digunakan dalam menurunkan kolesterol. Ekstrak etanol daun jati belanda mengandung flavonoid, saponin, dan tanin dengan kadar tinggi (Sari dkk., 2013). Kandungan flavonoid dalam jati belanda dapat menurunkan kolesterol dengan mekanisme kerja menghambat enzim HMG CoA reduktase yang berperan dalam proses pembentukan kolesterol. Tanin memiliki aktivitas antihiperlipidemia dengan cara mengurangi absorbsi lipid dalam usus (Havsteen, 2002). Saponin dapat menghambat lipase pankreatik (Iswantini dkk., 2011).

$$
\text { Kelopak bunga rosella }
$$

mengandung beberapa senyawa fenolik sederhana dan beberapa senyawa flavonoid (antosianin, antosianidin, dan glikosida kuersetin), serta asam organik dan derivatnya (Zarabal dkk., 2012). Kandungan antosianin pada kelopak bunga rosella memiliki aktivitas antihiperlipidemia dengan mekanisme kerja sebagai inhibitor pankreatik lipase yang dapat menurunkan penyerapan dan pencernaan lipid makanan (Sari dkk., 2013). Kandungan asam pada kelopak bunga rosella juga dapat menghambat sintesis triasilgliserol, sehingga dapat menurunkan LDL (Hopkins dkk., 2013).

Pengkombinasian daun jati belanda dan kelopak bunga rosella dengan mekanisme kerja yang berbeda sangat memungkinkan untuk menghasilkan efek komplementer, sehingga efektivitasnya akan lebih baik. Kombinasi ekstrak etanol daun jati belanda dan ekstrak air kelopak bunga rosella mampu menurunkan kadar kolesterol total, trigliserida, kolesterol LDL, dan meningkatkan kadar HDL pada tikus percobaan (Sholihah, 2016).

Di pasaran terdapat beberapa produk jamu yang mengandung daun Jati belanda atau kelopak bunga rosella sebagai antihiperlipidemia, namun belum ada kombinasi antara keduanya. Jamu yang beredar di pasaran umumnya dalam bentuk simplisia, serbuk, kapsul, pil, dan tablet. Jamu tersebut identik memiliki bau dan rasa yang kurang menyenangkan. Oleh karena itu, diperlukan pengembangan formulasi salah satunya dalam bentuk sediaan granul effervescent. Granul effervescent dipilih karena bentuk sediaan ini 
mempunyai rasa yang menyenangkan, dapat memberikan efek menyegarkan, dapat menutupi rasa bahan aktif yang pahit, dan mudah digunakan (Allen, 2002).

Pada penelitian ini untuk mendapatkan suatu sediaan granul effervescent yang acceptable, dibutuhkan jumlah asam basa yang optimum. Sumber asam dan basa yang digunakan adalah asam sitrat dan natrium bikarbonat. Asam sitrat memiliki kelarutan tinggi dalam air dan mudah diperoleh dalam bentuk granular. Natrium bikarbonat dapat larut sempurna, murah, dan banyak tersedia secara komersial mulai dari bentuk bubuk sampai bentuk granul (Mohrle, 1989). Optimasi asam sitrat dan natrium bikarbonat ini dilakukan dengan menggunakan metode desain faktorial untuk mendapatkan suatu formula optimum yang memenuhi persyaratan. Respon dalam penelitian ini meliputi waktu larut dan kelembaban granul effervescent.

\section{Metode Penelitian}

\section{Alat dan Bahan}

Alat-alat yang digunakan dalam penelitian ini adalah seperangkat alatalat gelas, grinder mixer (Orsatti Single
Phase Motor), rotary evaporator (Laboratta 4000-efficient), oven (Memmert), panci infus, kompor gas, freeze dryer (Zirbus VacO 5-II-D), spatula, lemari pendingin, timbangan analitik (Adventure Ohaus), alat penguji sifat alir dan sudut diam (Pharmeq), alat uji bobot jenis mampat (TAP-28, Logan instrumens), $\mathrm{pH}$ meter (CP 502 Elmeiron), ayakan mesh 100 (Pharmeq), mortir dan stamper, cawan penguap, desikator dan perangkat lunak Design Expert Trial 10.0.6.

Bahan yang digunakan meliputi daun jati belanda dan kelopak bunga rosella yang diperoleh dari daerah Kabupaten Jember, akuades, dekstrin, etanol $96 \%$, etanol $70 \%$ diperoleh dari Aneka Kimia. Natrium bikarbonat, asam sitrat, PVP, aspartam, dan laktosa diperoleh dari Bratachem.

\section{Jalannya Penelitian}

1. Persiapan ekstrak

Serbuk daun G. ulmifolia dimaserasi dengan etanol $96 \%$ selama 24 jam. Ekstrak hasil maserasi kemudian disaring dan residu kemudian dimaserasi lagi dengan etanol 96\% selama 24 jam. Ekstrak etanol diuapkan menggunakan rotary evaporator pada suhu $60^{\circ} \mathrm{C}$. Serbuk kelopak bunga H. sabdariffa 
diekstraksi dengan metode infus selama 15 menit pada suhu $90{ }^{\circ} \mathrm{C}$. Setelah itu disaring dan dikeringkan menggunakan freeze dryer.

2. Pembuatan granul effervescent
Granul effervescent dibuat menjadi empat rancangan formula, yaitu F1, Fa, Fb, Fab. Formulasi keempat granul dapat dilihat pada Tabel 1.

Tabel 1. Susunan formula granul effervescent

\begin{tabular}{lcccc}
\hline \multirow{2}{*}{ Bahan } & \multicolumn{4}{c}{ Formula $(\mathbf{m g})$} \\
\cline { 2 - 5 } & $\mathbf{F 1}$ & $\mathbf{F a}$ & $\mathbf{F b}$ & Fab \\
\hline Ekstrak jati belanda & 1001 & 1001 & 1001 & 1001 \\
Ekstrak rosella + dekstrin & 1512 & 1512 & 1512 & 1512 \\
Asam sitrat & 600 & 1200 & 600 & 1200 \\
Natrium bikarbonat & 720 & 720 & 1440 & 1440 \\
PVP & 60 & 60 & 60 & 60 \\
Aspartam & 180 & 180 & 180 & 180 \\
Pewarna yellow & 2 tetes & 2 tetes & 2 tetes & 2 tetes \\
Laktosa & ad 6000 & ad 6000 & ad 6000 & ad 6000 \\
\hline
\end{tabular}

Granul asam dibuat dengan mencampurkan ekstrak kering rosella, ekstrak daun jati belanda, laktosa, dan aspartam dalam mortir. Larutan PVP dicampurkan sedikit demi sedikit sampai terbentuk granul. Granul basa dibuat dengan mencampurkan natrium bikarbonat dan pewarna yellow. Larutan PVP dicampurkan sedikit demi sedikit. Semua granul diayak menggunakan ayakan 16 mesh dan dikeringkan dalam oven selama 2 hari.

3. Evaluasi granul effervescent

a. Uji organoleptis
Pengujian dilakukan dengan melihat tampilan dari granul effervescent. Pemeriksaan yang dilakukan meliputi warna, aroma, dan kondisi granul.

b. Laju alir dan sudut diam

100 gram granul ditimbang lalu dimasukkan ke dalam corong flowability tester, kemudian penutup dasar corong dibuka sambil dijalankan alat pencatat waktu. Laju alir dinyatakan dalam gram/detik. Pengukuran sudut diam ( $\alpha$ ), tinggi kerucut (h) dan jari-jari ( $r$ ) dasar kerucut granul 
yang terbentuk dilakukan setelah granul mengalir bebas. Kecepatan alir dan sudut diam dapat dihitung menggunakan persamaan berikut:

Kecepatan alir $=\frac{\text { Berat granul }}{\text { Waktu alir }}$

Sudut diam $=\alpha=\tan \left(\frac{\text { Tinggi kerucut }(h)}{\text { Jari jari }(r)}\right)$

\section{c. Bulk density dan tap density}

Tiga puluh gram granul dari setiap formula dimasukkan ke dalam gelas ukur $100 \mathrm{~mL}$ dan dicatat volume awal $\left(\mathrm{V}_{0}\right)$, kemudian gelas ukur dipasang pada alat, dan alat dihidupkan. Pengetapan dilakukan sampai 500 kali ketukan atau sampai diperoleh volume konstan, kemudian volume konstan $\left(\mathrm{V}_{\mathrm{t}}\right) \quad$ dicatat. Kompresibilitas granul dihitung menggunakan rumus Carr's Index dan Hausner Ratio, seperti pada persamaan berikut:

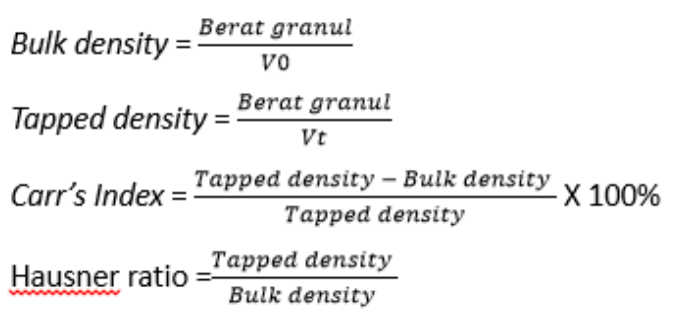

d. Kandungan lembab granul
Enam gram granul dimasukkan ke dalam alat moisture content analyzer. Alat dijalankan dengan mengatur suhu hingga $105^{\circ} \mathrm{C}$.

e. Uji waktu larut

Enam gram granul dimasukkan ke dalam gelas berisi akuades sebanyak $200 \mathrm{~mL}$. Waktu larut ditentukan mulai dari granul dimasukan ke dalam gelas hingga seluruh granul larut dalam akuades tersebut.

f. Uji pH

6 gram dilarutkan dalam beaker glass berisi air sebanyak $200 \mathrm{~mL}$. Alat $\mathrm{pH}$ meter yang akan digunakan sebelumnya dikalibrasi terlebih dahulu dengan menggunakan larutan buffer $\mathrm{pH}$ 7. Selanjutnya elektroda dicelupkan ke dalam sampel dan dibiarkan beberapa saat sampai diperoleh nilai $\mathrm{pH}$ sampel yang stabil.

g. Analisis desain faktorial dan penentuan daerah optimum

Hasil penentuan nilai waktu larut dan kelembaban kemudian dilakukan analisis dengan menggunakan software design expert trial 10.0.6 untuk menentukan formula optimum. Contour plot yang didapat 
kemudian digabungkan menjadi contour plot super imposed untuk mengetahui daerah komposisi optimum dari natrium bikarbonat dan asam sitrat yang digunakan untuk pembuatan granul effervescent.

h. Uji kesukaan

Metode yang digunakan adalah accidental sampling, dengan jumlah responden. Karakteristik responden yang diambil yaitu lakilaki dan perempuan di daerah Jember, usia 20-50 tahun. Tiap responden mendapatkan kesempatan yang sama untuk mencoba keempat formula granul effervescent kombinasi ekstrak jati belanda dan rosella. Responden tersebut kemudian memberikan penilaian terhadap warna, aroma dan rasa dari granul effervescent yang dicoba. Setelah itu, responden mengisi form atau angket penilaian yang tersedia. Hasil uji selanjutnya dianalisis secara statistik dengan uji KruskalWallis.

\section{Hasil dan Pembahasan}

Hasil ekstraksi daun G. Ulmifolia yang diperoleh sebesar 37,163 $\pm 0,105$ gram, dengan rendemen sebesar 6,194ะ0,017\%. Ekstrak kering kelopak bunga $H$. sabdariffa yang diperoleh sebanyak 40,27士0,105 gram, dengan rendemen sebesar 13,422 $\pm 0,035 \%$. Hasil ekstrak yang diperoleh dapat dilihat pada Gambar 1. (a)

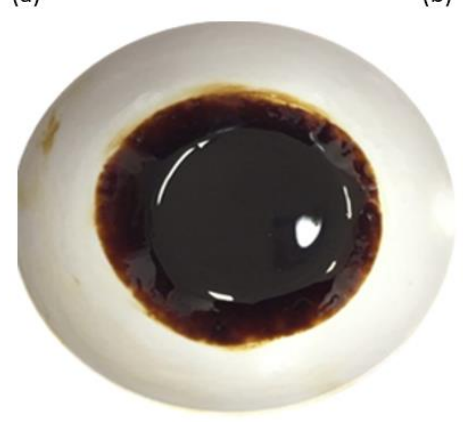

(b)

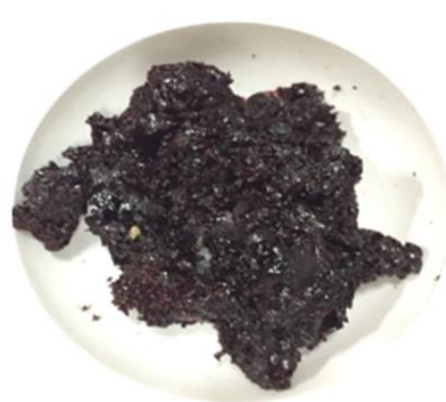

Gambar 1. Ekstrak jati belanda (a) dan ekstrak rosella (b).

\section{Evaluasi Granul}

Hasil pemeriksaan organoleptis granul effervescent dapat dilihat pada
Tabel 2. Hasil keempat formula granul effervescent dapat dilihat pada Gambar 2. 
Data uji organoleptis yang kuning pada granulnya. Hal ini diperoleh menunjukkan bahwa tidak ada dikarenakan pada granul basa perbedaan aroma dan kondisi granul ditambahkan pewarna yellow sehingga effervescent pada keempat formula, granul basa berwarna kuning, dengan namun terdapat perbedaan pada demikian campuran granul yang tampilan warna. Pada formula $b$ dan $a b$ mengandung jumlah basa tinggi akan cenderung memiliki banyak warna memiliki warna yang lebih kuning.

Tabel 2. Hasil uji organoleptis granul effervescent

\begin{tabular}{cccc}
\hline Formula & Warna & Aroma & Kondisi Granul \\
\hline 1 & Coklat & Sedikit berbau & Kering dan kasar \\
$\mathrm{a}$ & Coklat & Sedikit berbau & Kering dan kasar \\
$\mathrm{b}$ & Coklat kekuningan & Sedikit berbau & Kering dan kasar \\
$\mathrm{ab}$ & Coklat kekuningan & Sedikit berbau & Kering dan kasar \\
\hline
\end{tabular}

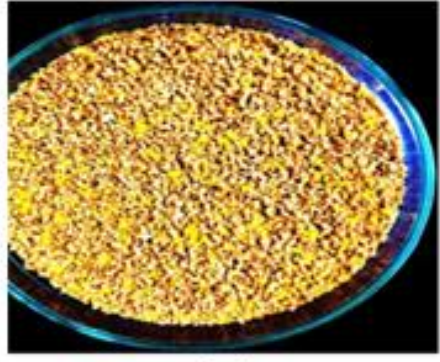

(a)

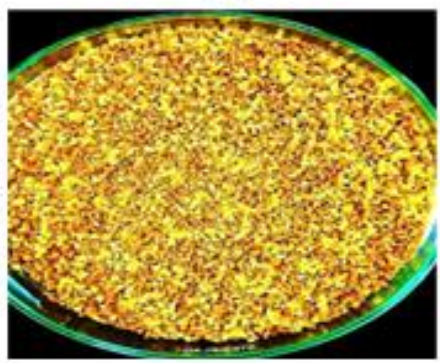

(c)

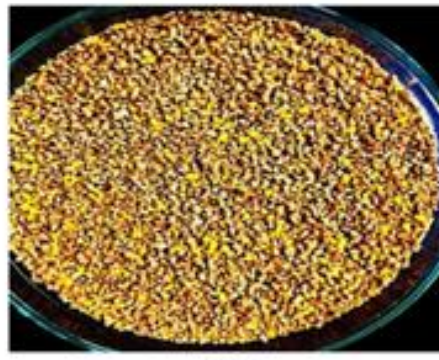

(b)

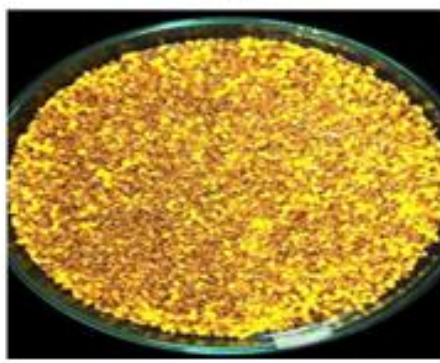

(d)

Gambar 2. Granul effervescent (a) formula 1, (b) formula a, (c) formula b, (d) formula ab.

Berdasarkan pengujian laju alir menunjukkan bahwa semua granul effervescent yang dihasilkan memiliki waktu alir yang baik. Waktu alir granul yang baik adalah lebih dari 10 gram/detik (Fadlil dkk., 2012). Hasil 
pengujian laju alir granul effervescent untuk setiap formula dapat dilihat pada Tabel 3.

Hasil pengujian sudut diam granul effervescent berada pada rentang
27,89-28,81 derajat. Nilai sudut diam granul yang baik apabila tidak lebih dari $30^{\circ}$ (Patel dkk., 2012). Hasil pengujian sudut diam granul effervescent dapat dilihat pada Tabel 4.

Tabel 3. Hasil uji laju alir granul effervescent

\begin{tabular}{ccccc}
\hline \multirow{2}{*}{ Replikasi } & \multicolumn{4}{c}{ Kecepatan Alir (gram/detik) } \\
\cline { 2 - 5 } & $\mathbf{F 1}$ & $\mathbf{F a}$ & $\mathbf{F b}$ & Fab \\
\hline 1 & 11,223 & 10,953 & 11,249 & 11,07 \\
2 & 11,074 & 10,87 & 11,534 & 10,929 \\
3 & 11,682 & 11,148 & 11,39 & 11,152 \\
\hline Rata-rata & 11,33 & 10,99 & 11,39 & 11,05 \\
SD & 0,317 & 0,143 & 0,143 & 0,113 \\
\hline
\end{tabular}

Tabel 4. Hasil uji sudut diam effervescent

\begin{tabular}{ccccc}
\hline \multirow{2}{*}{ Replikasi } & \multicolumn{4}{c}{ Sudut Diam (Derajat) } \\
\cline { 2 - 5 } & $\mathbf{F 1}$ & $\mathbf{F a}$ & $\mathbf{F b}$ & Fab \\
\hline 1 & 28,258 & 28,258 & 27,699 & 27,699 \\
2 & 27,699 & 28,811 & 28,258 & 28,811 \\
3 & 28,811 & 29,358 & 27,699 & 29,358 \\
\hline Rata-rata & 28,26 & 28,81 & 27,89 & 28,62 \\
SD & 0,556 & 0,550 & 0,323 & 0,845 \\
\hline
\end{tabular}

Hasil yang diperoleh dari persen kompresibilitas menunjukkan nilai Carr's Index berkisar antara 10,71$11,73 \%$. Hasil ini sesuai dengan literatur yang menyatakan bahwa granul yang memiliki nilai Carr's Index kurang dari 15\% memiliki kemampuan alir yang baik (Patel dkk., 2012). Nilai Hausner's Ratio yang diperoleh dari keempat formula berkisar antara 1,12-1,13. Nilai Hausner's Ratio pada rentang 1,00-1,18 dikatakan memiliki kemampuan alir yang baik. Hasil pengujian sudut diam granul effervescent dapat dilihat pada Tabel 5.

Hasil pengujian $\mathrm{pH}$ granul effervescent yang diperoleh berkisar antara 6,08-6,42. Berdasarkan data yang diperoleh menunjukkan bahwa nilai $\mathrm{pH}$ dari keempat formula telah memenuhi nilai $\mathrm{pH}$ effervescent yang baik yaitu 6-7 (Kailaku dkk., 2012). 
Pengukuran $\mathrm{pH}$ perlu dilakukan karena jika larutan effervescent yang terbentuk terlalu asam dapat mengiritasi lambung sedangkan jika terlalu basa menimbulkan rasa pahit dan tidak enak. Hasil pengujian pH granul effervescent dapat dilihat pada Tabel 6.

Tabel 5. Hasil uji sudut diam granul effervescent

\begin{tabular}{cccc}
\hline \multirow{2}{*}{ Formula } & \multicolumn{2}{c}{ Kompresibilitas (Rata-Rata) } & \multirow{2}{*}{ Kemampuan Alir } \\
\cline { 2 - 3 } & Carr's index (\%) & Hausner's ratio & \\
\hline 1 & $11,44 \pm 0,938$ & $1,13 \pm 0,012$ & Baik \\
a & $11,73 \pm 1,087$ & $1,13 \pm 0,014$ & Baik \\
b & $11,25 \pm 1,891$ & $1,13 \pm 0,024$ & Baik \\
ab & $10,71 \pm 1,786$ & $1,12 \pm 0,022$ & Baik \\
\hline
\end{tabular}

Tabel 6. Hasil uji pH granul effervescent

\begin{tabular}{ccccc}
\hline Replikasi & $\mathbf{F 1}$ & $\mathbf{F a}$ & $\mathbf{F b}$ & $\mathbf{F a b}$ \\
\hline 1 & 6,28 & 6,12 & 6,49 & 6,26 \\
2 & 6,32 & 6,04 & 6,38 & 6,20 \\
3 & 6,26 & 6,18 & 6,45 & 6,15 \\
\hline Rata-rata & 6,29 & 6,11 & 6,44 & 6,20 \\
SD & 0,031 & 0,070 & 0,056 & 0,055 \\
CV & 0,486 & 1,149 & 0,865 & 0,89 \\
\hline
\end{tabular}

Pengujian pH menunjukkan formula a memiliki nilai $\mathrm{pH}$ yang paling rendah, sedangkan formula $b$ memiliki nilai $\mathrm{pH}$ yang paling tinggi. Hal tersebut dikarenakan terdapat perbedaan kompenan asam dan basa. Variasi jumlah asam dan basa mempengaruhi $\mathrm{pH}$ sediaan. Semakin banyak jumlah asam sitrat yang digunakan, maka $\mathrm{pH}$ sediaan semakin menurun.
Hasil uji kelembaban granul effervescent diperoleh kandungan lembab yang berkisar antara 1,822,40\%. Berdasarkan hasil tersebut, keempat formula memenuhi persyaratan kelembaban granul effervescent dari bahan ekstrak yaitu $\leq$ 5\% (BPOM, 2014). Hasil uji kelembaban granul effervescent dapat dilihat pada Tabel 7. 
Tabel 7. Hasil uji kelembaban granul effervescent

\begin{tabular}{ccccc}
\hline \multirow{2}{*}{ Replikasi } & \multicolumn{4}{c}{ Kelembaban (\%) } \\
\cline { 2 - 5 } & F1 & Fa & Fb & Fab \\
\hline 1 & 2,2 & 2,2 & 2,15 & 2 \\
2 & 2,15 & 2,6 & 1,7 & 2,15 \\
3 & 2,35 & 2,4 & 1,6 & 2,3 \\
\hline Rata-rata & 2,23 & 2,40 & 1,82 & 2,15 \\
SD & 0,104 & 0,200 & 0,293 & 0,150 \\
\hline
\end{tabular}

Pengujian

kelembaban

menunjukkan bahwa formula a memiliki nilai kelembaban yang paling tinggi, sedangkan formula $b$ memiliki nilai kelembaban yang paling rendah. Hal ini dikarenakan pada formula $b$ mengandung natrium bikarbonat level tinggi, natrium bikarbonat dapat menstabilkan asam sitrat yang bersifat higroskopis (menyerap air) sehingga semakin tinggi konsentrasi natrium bikarbonat yang ditambahkan maka akan semakin sedikit uap air yang terserap (Sandrasari dan Abidin, 2010). Granul effervescent yang memiliki kelembaban tinggi akan menyebabkan terjadinya reaksi effervescent yang prematur sehingga granul effervescent menjadi tidak stabil (Purwandari, 2007).

Hasil waktu larut yang diperoleh menunjukkan bahwa semua formula granul telah memenuhi persyaratan waktu larut yaitu kurang dari 150 detik (Wehling, 2004). Hasil uji kelembaban granul effervescent dapat dilihat pada Tabel 8. Pengujian waktu larut granul effervescent menunjukkan bahwa formula (b) yang mengandung natrium bikarbonat level tinggi dan asam sitrat level rendah memiliki waktu larut yang paling cepat. Formula a yang mengandung natrium bikarbonat level rendah dan asam sitrat level tinggi memiliki waktu larut yang paling lama. Perbedaan waktu larut ini dipengaruhi oleh penggunaan jumlah natrium bikarbonat dan asam sitrat. Hal tersebut juga berhubungan dengan kandungan lembab granul, semakin rendah kandungan lembab granul maka semakin mudah untuk menarik air yang ada di sekitarnya sehingga granul akan mudah pecah dan terlarut (Purwandari, 2007). Hasil uji kelembaban juga menunjukkan bahwa formula b memiliki kandungan lembab yang paling rendah dibanding formula yang lain. 
Tabel 8. Hasil uji waktu larut granul effervescent

\begin{tabular}{ccccc}
\hline \multirow{2}{*}{ Replikasi } & \multicolumn{4}{c}{ Waktu Larut (detik) } \\
\cline { 2 - 5 } & F1 & Fa & Fb & Fab \\
\hline 1 & 110 & 125 & 83 & 87 \\
2 & 115 & 132 & 90 & 100 \\
3 & 120 & 130 & 92 & 95 \\
\hline Rata-rata & 115 & 129 & 88,33 & 94 \\
SD & 5 & 3,6 & 5,35 & 6,97 \\
\hline
\end{tabular}

Hasil uji kesukaan terhadap skor warna, aroma, dan rasa granul effervescent dari keempat formula dapat dilihat pada Gambar 3. Penilaian kesukaan terhadap warna ditunjukkan warna biru, penilaian kesukaan aroma ditunjukkan warna merah, dan penilaian kesukaan rasa ditunjukkan warna hijau. Skor 1 adalah sangat tidak suka, skor 2 adalah tidak suka, skor 3 adalah cukup suka, skor 4 adalah suka, dan skor 5 adalah sangat suka.

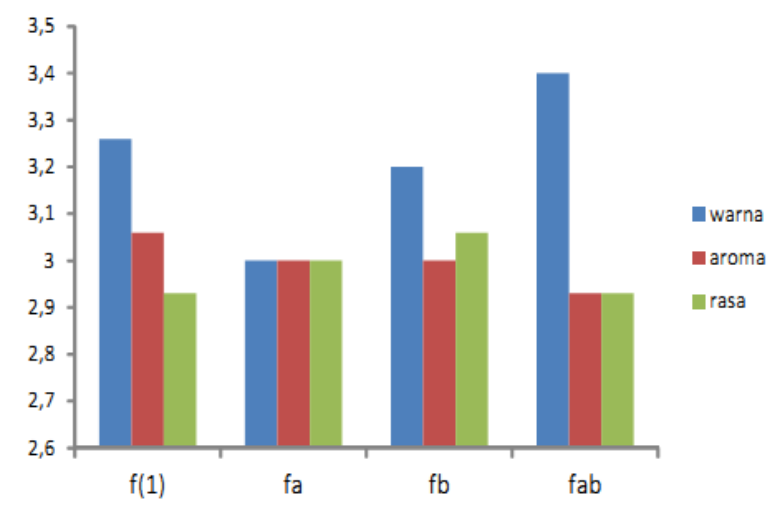

Gambar 3. Hasil uji kesukaan granul effervescent.

Hasil penilaian formula 1 yang didapat menunjukkan skor 3,26 pada penilaian warna, skor 3,06 pada penilaian aroma, dan skor 2,93 pada penilaian rasa. Hasil formula a menunjukkan skor 3 pada penilaian warna, aroma, dan rasa. Hasil formula b menunjukkan skor 3,2 pada penilaian warna, skor 3 pada penilaian aroma, dan skor 3,06 pada penilaian rasa, sedangkan pada formula ab menunjukkan skor 3,4 pada penilaian warna, skor 2,93 pada penilaian aroma, dan skor 2,93 pada penilaian rasa. 
Penilaian kesukaan terhadap warna ditunjukkan warna biru, penilaian kesukaan aroma ditunjukkan warna merah, dan penilaian kesukaan rasa ditunjukkan warna hijau. Skor 1 adalah sangat tidak suka, skor 2 adalah tidak suka, skor 3 adalah cukup suka, skor 4 adalah suka, dan skor 5 adalah sangat suka.

Hasil penilaian formula 1 yang didapat menunjukkan skor 3,26 pada penilaian warna, skor 3,06 pada penilaian aroma, dan skor 2,93 pada penilaian rasa. Hasil formula a menunjukkan skor 3 pada penilaian warna, aroma, dan rasa. Hasil formula b menunjukkan skor 3,2 pada penilaian warna, skor 3 pada penilaian aroma, dan skor 3,06 pada penilaian rasa, sedangkan pada formula ab menunjukkan skor 3,4 pada penilaian warna, skor 2,93 pada penilaian aroma, dan skor 2,93 pada penilaian rasa.

Hasil rekapitulasi uji kesukaan terhadap aroma, warna, dan rasa granul effervescent kemudian dianalisis Kruskal-Wallis untuk mengetahui apakah terdapat perbedaan dari masing-masing formula. Hasil yang didapat diperoleh nilai signifikansi $>0,05$ yang berarti tidak ada perbedaan yang bermakna terhadap warna, aroma, dan rasa granul effervescent dari formula optimum maupun ketiga formula yang lain. Dengan demikian, antara formula optimum dan ketiga formula yang lain sama-sama disukai oleh responden.

Penentuan formula optimum granul effervescent dilakukan dengan cara menggabungkan contour plot dari kedua respon waktu larut dan kelembaban menjadi overlay plot. Area optimum yang diperoleh dapat dilihat dari overlay plot pada Gambar 4, area optimum overlay plot ditunjukkan oleh daerah yang berwarna kuning. Area berwarna kuning merupakan perpotongan dari kedua respon yang memenuhi semua kriteria waktu larut dan kelembaban, sedangkan daerah yang berwarna abu-abu adalah daerah di luar daerah optimum yang tidak masuk kriteria respon yang diinginkan. Daerah berwarna kuning pada overlay plot dapat menunjukkan rentang komposisi optimum masing-masing faktor. 

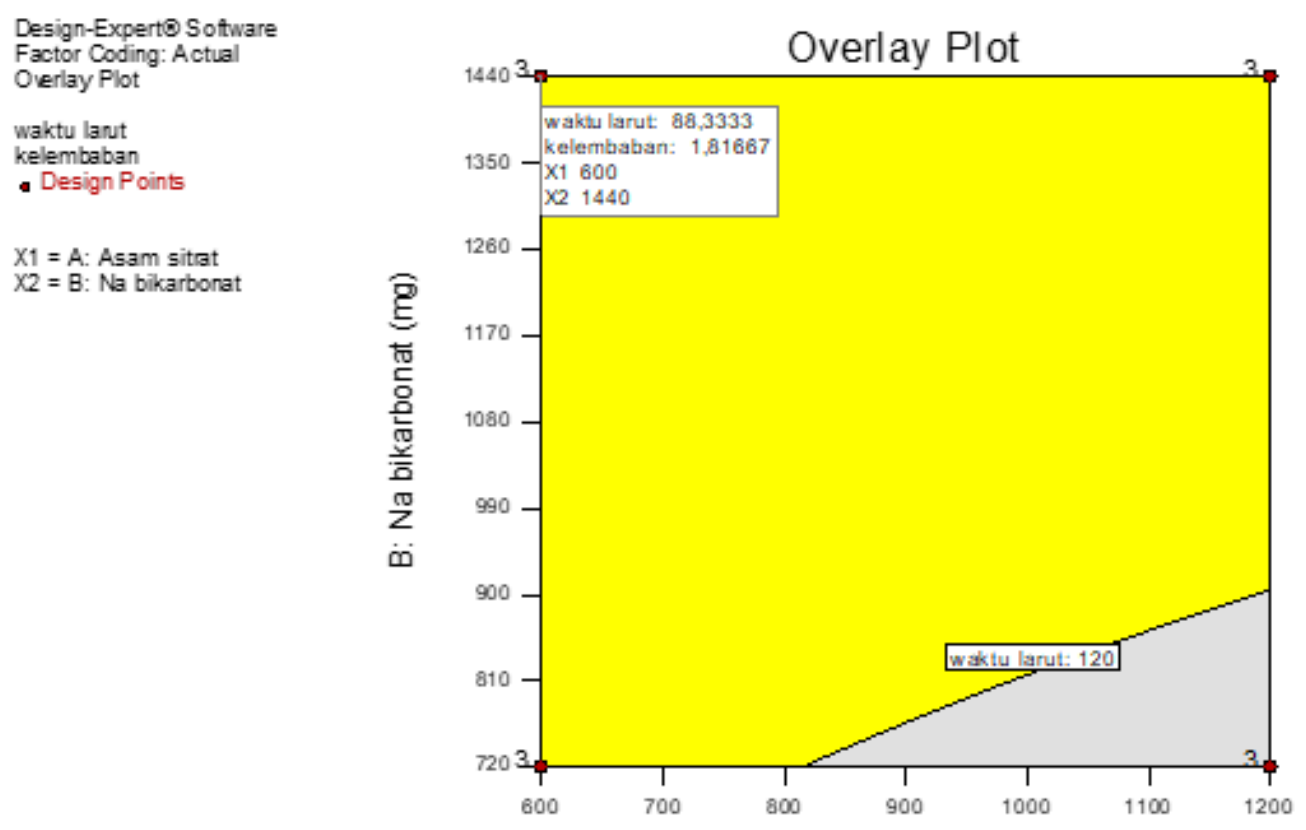

A: Asamsitrat (mg)

Gambar 4. Overlay plot.

Berdasarkan hasil analisis tersebut diperoleh 4 komposisi formula optimum. Formula optimum tersebut didapatkan melalui hasil analisis menggunakan Design Expert Trial dengan batas minimum dan maksimum respon kelembaban 1-3\% serta batas respon yang maksimum pada waktu larut. Formula yang paling baik dari keempat formula optimum yang didapat dari Desain Expert Trial adalah formula yang mengandung asam sitrat sebesar $600 \mathrm{mg}$ dan natrium bikarbonat sebesar $1440 \mathrm{mg}$, dengan prediksi waktu larut 88,33 detik dan kelembaban $1,81 \%$. Komposisi formula tersebut sama dengan formula $b$.

\section{Kesimpulan}

Berdasarkan hasil penelitian yang sudah dilakukan dapat disimpulkan bahwa semakin banyak jumlah asam sitrat yang digunakan akan meningkatkan waktu larut dan kelembaban granul effervescent, sebaliknya semakin banyak jumlah natrium bikarbonat yang digunakan akan menurunkan waktu larut dan kelembaban granul effervescent. Berdasarkan overlay plot didapatkan 
komposisi optimum yaitu pada formula

b dengan jumlah asam sitrat sebesar

$600 \mathrm{mg}$ dan natrium bikarbonat sebesar $1440 \mathrm{mg}$ dengan prediksi kelembaban

$1,81 \%$ dan waktu larut 88,33 detik.

\section{Daftar Pustaka}

Allen, V.L. 2002. The Art, Science and Technology of Pharmaceutical Compounding. Edisi 2. Washington D.C: American Pharmaceutical Assosiation.

BPOM. 2014. Persyaratan Mutu Obat Tradisional. Jakarta: Badan Pengawas Obat dan Makanan Republik Indonesia.

Fadlil, A., Aji, W.S., Azis, N., Setianto, A.B. 2012. Rancang Bangun Sistem Instrumentasi Otomatis Uji Kecepatan Alir Granul/Serbuk Obat. Prosiding Seminar Nasional Aplikasi Sains dan Teknologi Periode III. (November), Yogyakarta.

Havsteen, B.H. 2002. The biochemistry and medical significance of the flavonoids. Pharmacology and Therapeutics, 96(2-3):67-202.

Hopkins, A.L., Lamm, M.G., Funk, J.L., Ritenbaugh, C. 2013. Hibiscus sabdariffa $\mathrm{L}$. in the treatment of hypertension and hyperlipidemia: a comprehensive review of animal and human studies. Fitoterapia, 85(1):84-94.

Iswantini, D., Silitonga, R.F., Martatilofa, E., Darusman, L.K. 2011. Zingiber cassumunar, Guazuma ulmifolia, and Murraya paniculata extracts as antiobesity: in vitro inhibitory effect on pancreatic lipase activity. Hayati Journal of Biosciences, 18(1):6-10.

Kailaku, S.I., Sumangat, J., Hernani. 2012. Formulasi granul efervesen kaya antioksidan dari ekstrak daun gambir. J. Pascapanen, 9(1):27-34.

Mohrle, R. 1989. Effervescent Tablet. Dalam Pharmaceutical Dosage Form: Tablet. New York: Marcel Dekker, Inc.

Sandrasari, D.A dan Abidin, Z. 2010. Penentuan konsentrasi natrium bikarbonat dan asam sitrat pada pembuatan serbuk minuman anggur berkarbonasi (effervescent). J. Tek. Ind. Pert, 21(2):113-117.

Sari, I.P., Nurrochmad, A., Setiawan, I.M. 2013. Indonesian herbals reduce cholesterol levels in diet induced hypercholesterolemia through lipase inhibition. Malaysian Journal of Pharmaceutical Sciences, 11(1):13-20.

Sholihah, M. 2016. Uji aktivitas antihiperlipidemia kombinasi ekstrak daun jati belanda (Guazuma ulmifolia Lamk.) dan kelopak bunga rosella (Hibiscus sabdariffa L.) pada tikus putih jantan galur wistar (Rattus norvegicus). Skripsi. Fakultas Farmasi, Universitas Jember.

Patel, H.K., Chauhan, P., Patel, K.N., Patel, B.A. Patel, P.A. 2012. 
Formulation and evaluation of effervescent tablet of paracetamol and ibuprofen. International Journal for Pharmaceutical Research Scholars, 1(2):509-520.

Purwandari, L.E. 2007. Optimasi campuran asam sitrat-asam tartrat dan natrium bikarbonat sebagai eksipien dalam pembuatan granul effervescent ekstrak. Skripsi. Fakultas Farmasi, Universitas Sanata Dharma Yogyakarta.
Wehling, F. 2004. Effervescent Composition Including Stevia. http://www.google.ch/patents/ US6811793 [Diakses pada 20 April 2014].

Zarabal, O.C., Maria, D., Dermitz, B., Flores, Z.O., Margaret, P., Jones, H., Hipolito, C.N., Bin Bujang, K. 2012. Hibiscus sabdariffa L, Roselle calyx, from ethnobotany to pharmacology. Journal of Experimental Pharmacology, 4:25-39. 